\title{
Renal Cell Carcinoma Associated with $\operatorname{inv}(X)(p 11 ; q 12)$
}

National Cancer Institute

\section{Source}

National Cancer Institute. Renal Cell Carcinoma Associated with inv(X)(p11:q12). NCI

Thesaurus. Code C39802.

A renal cell carcinoma with papillary architecture comprised of clear cells. It is characterized by the inv $(X)(p 11 ; q 12)$ resulting in fusion of the NONO (p54nrb) and TFE3 genes. 